\title{
A Staged Approach for Energy Retrofitting an Old Service Building: A Cost-Optimal Assessment
}

\author{
Jorge Lopes ${ }^{1, *}$, Rui A. F. Oliveira ${ }^{1}\left(\mathbb{D}\right.$, Nerija Banaitiene ${ }^{2}\left(\mathbb{D}\right.$ and Audrius Banaitis ${ }^{2, *} \mathbb{C}$ \\ 1 Department of Construction and Planning, Polytechnic Institute of Bragança, Campus de Santa Apolonia, \\ 5300-253 Bragança, Portugal; roliveira@ipb.pt \\ 2 Department of Construction Management and Real Estate, Vilnius Gediminas Technical University, \\ 10223 Vilnius, Lithuania; nerija.banaitiene@vilniustech.lt \\ * Correspondence: lopes@ipb.pt (J.L.); audrius.banaitis@vilniustech.lt (A.B.)
}

check for updates

Citation: Lopes, J.; Oliveira, R.A.F.; Banaitiene, N.; Banaitis, A. A Staged Approach for Energy Retrofitting an Old Service Building: A Cost-Optimal Assessment. Energies 2021, 14, 6929. https://doi.org/10.3390/en14216929

Academic Editors: Alessia Arteconi and José Matas

Received: 29 August 2021

Accepted: 15 October 2021

Published: 21 October 2021

Publisher's Note: MDPI stays neutral with regard to jurisdictional claims in published maps and institutional affiliations.

Copyright: (c) 2021 by the authors. Licensee MDPI, Basel, Switzerland. This article is an open access article distributed under the terms and conditions of the Creative Commons Attribution (CC BY) license (https:// creativecommons.org/licenses/by/ $4.0 /)$.

\begin{abstract}
Office buildings built before the pre-1960 age constitute a relevant group for analyzing the energy performance of the Portuguese building sector. A dynamic energy simulation was used to assess the energy performance of an existing office building located in the town of Bragança, Portugal. By using a staged renovation approach, two passive technologies applied to the building envelope and an efficient domestic hot water system were selected and a financial evaluation through the net saving (NS) method was undertaken to choose the best efficiency measures/packages for improving the building's energy performance. Real discount rates of $3 \%$ and $1 \%$ were used in the financial evaluation. Considering the real discount rate of $3 \%$, the results showed that only two out seven retrofit options had a positive financial return. By using the real discount rate of $1 \%$, all retrofit options were found to be financially efficient. The results of the study corroborated those of earlier works that found that the financial profitability of energy renovation investments is very sensitive to the discount rate used in the analysis. The results of the study also suggested that the staged renovation approach used in the analysis is economically feasible, and that this approach is an alternative to one-step renovation approach to help to achieve the country's energy and climate targets by 2030. Suggestions for future research conducted for office buildings in the different climate zones and other age groups in Portugal are proposed.
\end{abstract}

Keywords: building retrofitting; cost-optimality; dynamic energy simulation; economic assessment; energy performance; staged renovation

\section{Introduction}

The European Union (EU), as a signatory of the Paris Climate Agreement, has committed to contribute to controlling greenhouse gas (GHG) emissions, limiting the increase in global temperatures to well below $2{ }^{\circ} \mathrm{C}$ during this century, with pre-industrial age levels taken as the benchmark [1]. Globally, energy is responsible for about three-quarters of GHG emissions. In the EU, buildings account for about $36 \%$ of $\mathrm{CO} 2$ emissions and represent about $40 \%$ of energy consumption-the largest sector in all end-users area [2,3]. The residential building segment alone represented about $27 \%$ of EU's final energy consumption in 2014 [4]. However, the construction and property sectors represent the largest source of potential energy savings and GHG emissions reduction in Europe and worldwide [5,6]. In the mix of the building sector's energy consumption, operating (80-90\%) and embodied (10-20\%) phases of energy use are significant contributors to building's life cycle of energy demand [7]. Thus, an efficient strategy for the decarbonization of the construction and property sectors has to encompass both the construction phase and the operating phase of buildings and other constructed facilities.

In the EU, the demand for energy for buildings is mainly caused by low levels of energy efficiency in buildings_-around 75\% of buildings are inefficient [8]. This fact is also related to the construction period, and it is estimated that $40 \%$ of residential buildings were 
built before 1960, a time when construction regulations were very limited [9]. Realizing the potential associated with the building sector requires a strategy that should not be limited to stricter control in new building but should also provide more efficient solutions for existing buildings [10]. With estimates showing that $75-85 \%$ of the current EU building stock will still exist in 2050, the renovation of the national building stock is a key element for attaining the EU's energy and climate goals [11].

The EU key policy instrument for reducing energy use in buildings is the Energy Performance of Buildings Directive-EPBD [2], accompanied by provisions for the building sector in other directives, specifically the Energy Efficiency Directive-EED [12] and Renewables Energy Directive-RED [13,14]. The Article 5 of the recast EPBD states that Member States (MS) shall take the necessary measures to ensure that minimum energy performance requirements for buildings or building units are set with a view to achieving cost-optimal levels. The EU Delegated Regulation N ${ }^{\circ}$. 244/2012 [15], supplementing Directive 2010/31/EU [16] introduced a harmonized calculation methodology for calculating cost-optimal levels of minimum energy performance requirements for buildings and building elements. The regulation prescribes that MS shall report to the European Commission all input data and assumptions used in those calculations. The Article 2a of the recast EPBD also includes a number of measures targeting energy efficiency improvements in buildings. These include the requirement for MS to establish a long-term renovation strategy (LTRS) for mobilizing investment in the renovation of the national stock of residential and commercial buildings, both public and private. The Article 2a of the EPBD also states that "the LTRS shall identify the cost-effective approaches (according to the comparative methodology of the EPBD) to renovation relevant to the building type and climatic zone. They shall also present the main policies and measures (including financial and tax instruments) to stimulate cost-effective deep renovations of buildings, including staged deep renovation, and a forward-looking perspective to guide investment decisions of individuals, the construction industry and financial institutions" [2].

Financial incentives have been developed (at EU and national levels) to improve the access to capital but they have also been developed to motivate consumers to take energy efficiency actions [17]. The financial instruments normally include subsidy/grant schemes, soft loans and funds. The subsidy/grant schemes are generally targeted to meet specific objectives and to promote deep renovations (generally public and residential building segments), which have high upfront costs [17]. However, despite this plethora of efficiency programs and supporting measures, the current levels of energy renovations in EU are still far from the optimal one [18]. There are many barriers faced by the sector, from technical barriers to regulatory and market risks [19]. According to Bertoldi et al. [20] one reason behind such a partial inefficacy might be related to the fact that informational measures aimed at encouraging renovation are poorly explained and understood. Moreover, renovation decisions are also influenced by personal (such as age) and other contextual factors related to everyday life [21].

The European Commission has recently launched a new specific strategy to promote renovations of buildings-A Renovation Wave for Europe-Greening our buildings, creating jobs, improving lives [19]. As part of the Renovation Wave strategy, the European Commission has strengthened its commitment to tackle energy poverty, in which renovation is acknowledged as a key strategy to address energy poverty [20]. Energy efficiency of buildings, particularly of the housing segment, is one of the flagship areas-RENOVATE-of the EU Recovery and Resilience Facility under the NextGenerationEU instrument [22]. With this strategy, the EU aims to reduce, by 2030 , buildings' GHG emissions by $60 \%$ and primary energy consumption by $14 \%$, with 2015 as the reference year. The general aim is to cut net GHG emissions by at least $55 \%$ by 2030 compared to 1990 [23]. However, the European Commission recognized that mobilizing investment is difficult, particularly at the local and regional level, and that public funds are frequently scarce and difficult to blend due to regulatory obstacles [19]. Thus, cost-effectiveness should be at the core of energy efficiency programs in the EU. A special report of the European Court of Auditors 
(ECA) suggested that cost-effectiveness is not a determining factor for public funding of energy efficiency in buildings [24], implying that some national and EU funded energy efficiency programs have not been developed in the spirit of the provisions contained in the EU Delegated Regulation and its accompanying Guidelines [25]. The ECA report also underlined that simple upgrades with high energy savings per euro invested are usually financially viable, and should therefore, generally, be financed by the private market [24].

Thus, new approaches must be explored to promote energy efficiency of buildings, and that staged renovation needs a fresher look from the part of national governments in the EU. Staged renovations are by far the most popular in many European countries [26]. The EPBD and the Renovation Wave strategy reference staged renovation as another suitable approach to energy renovation in buildings. In the published literature there has been an increasing interest in this approach as well [26-30]. Fritz et al. [26] analyzed how well-planned staged renovations can lead to highly efficient building based on the model calculations for typical German residential building. The model calculation demonstrated that while one-step renovation led to $20 \%$ higher energy savings over time for a multi-family building, the total cost in the staged renovation was $6 \%$ lower due to coupling renovation measures to the maintenance and repair works. Semprini et al. [31] analyzed a large set of possible scenarios for renovation as technical feasible solutions to achieve NZEB requirements, by using a multi-family housing in Bologna, Italy, as a case study. They then analyzed to what extent one-step renovation and high transformation of buildings is competitive with respect to shallow retrofit. By considering the SPB method, they found that payback times varied from 9 to 25 years for the standard renovation scenario and from 40 to 90 years in the deep renovation scenario, with or without incentives, respectively. The NPV analysis showed that potential margins of profitability were achievable by coupling the retrofit scenarios with RES systems. The step by step renovation approach has merited special consideration for the part of energy stakeholders in France, including the government. The French company Effinergy, in consortium with Pouget Consultants, EIRENO and the French Energy Agency (ADEME), developed a national methodology of step by step renovation, the so called B2C2 methodology or step by step BBC "bâtiment à basse consommation". This methodology is addressed at local authorities proposing financial assistance and support to home owners. It is composed, in particular, of the following tools: eight technical principles to secure and implement properly the steps, particularly the first step, which is focused on the building envelope; a guide book for local authorities, to help them implement the methodology [32]. It is worth noting the distinction between step by step BBC "BBC par étape" and compatible BBC "BBC compatible", the latter is associated with each lot of renovation works (walls, roof, etc.). This notion assures that the technical level defined for each lot is adequate with the attestation of BBC Effinergy level after the completion of the works. The former is associated with a roadmap with a complete picture, which will be conductive to the BBC requirements in the long-term. Both these notions are in line with the notion of building renovation passport (BRP), which was developed within the European Horizon 2020 funded iPRoad project. The BRP has been implemented in several countries sand is referenced in the revised EPBD [26].

Building is diverse and each country has its specificities, and climate has an important effect in the pattern of energy consumption. The pattern of energy consumption in Portugal is markedly different from that of the EU as a whole. In Portugal, in 2016, the transport sector was the main contributor with $37 \%$, followed by industry (31\%), building (29\%); divided into residential (16\%) and service buildings (13\%); agriculture and fisheries (3\%) [33]. The primary energy consumption in Portugal totaled $22.1 \mathrm{Mt}_{\mathrm{oe}}$ in 2016 . Compared with the mix of energy consumption registered in 2006, the two segments of the building sector, residential and service buildings, had, negative annual growth rates of $-2.6 \%$ and $-1.0 \%$, respectively. However, it is also worth noting that final energy consumption in service buildings has remained practically stagnant in the period 2011-2016, which reflected a positive development of the economy [33]. 
The LTRS, in a number of EU countries (including Portugal), have not presented a detailed information (if any) on the cost-effective approaches to renovations and priority groups of buildings nor have they provided a comprehensive analysis of the barriers to investment [14]. Like most of energy efficiency programs prevailing in the EU, the economic instruments to stimulate building's energy renovation market in Portugal are generally target for existing residential and public buildings [10,34]. Office buildings built before the entry into force of the first thermal regulation in 1991 [35] constitute a relevant group for assessing the energy performance of the Portuguese building sector. Of the country's builtup area, in $2014,77 \%$ was represented by residential buildings and $23 \%$ by commercial and service buildings [4]. The service segment is broken down in the following subsegments: private and public offices (26.6\%); schools (20.1\%); hospitals (6.9\%); hotels and restaurants $(13.5 \%)$; sports buildings $(4 \%)$; commerce $(27.2 \%)$; other $(1.7 \%)$. Office buildings built without thermal performance requirements represented about $20.1 \%$ of the gross floor area of the country's total non-residential segment and were responsible for about $38 \%$ of this building segment's final energy consumption in 2016 [10]. As the commercial and service building segment's final energy consumption in Portugal is not much dissimilar to that of the residential buildings, an approach focused on the former segment may provide new insights for assessing the consistency of Portugal's strategy for energy efficiency. The aim of this research is to explore the evaluation of energy building retrofits from a cost-effectiveness approach, within the context of the EU and Portugal's regulatory and policies frameworks for energy efficiency of the building sector. The paper is used as a case study of an existing large office building, located in the town of Bragança, Northeastern of Portugal, which is typical of the pre-1960 age.

The remainder of the paper is structured as follows: Section 2 provides a brief review on the economic evaluation of renovation investment in buildings; the methodology is presented in Section 3; Section 4 presents the obtained results of the application of the case study and provides an assessment of the results; a concluding remark is drawn in Section 5.

\section{A Brief Review on the Economic Evaluation of Building Renovation Investments}

Research into the use of energy in buildings goes back to the 1970s and the first oil crisis [36]. In the United States, economic evaluation of public investment takes place in the early 1980s, in the aftermath of the second oil crisis in 1979-1980 [37]. The Building Economics Subcommittee was established in 1979 within the ASTM Committee E06 on the Performance of Buildings [38]. Energy and economic benefits are the main objectives in building renovation. However, other non-energy objectives have also to be considered to expand the feasibility of transforming existing buildings in low-energy buildings [31,39]. Since 2000's, an increasing amount of literature dealing with building renovation investments has been published. Most of these works follow more of less closely the EU comparative methodology framework, which, in its essence, follows the classical framework of the net present value (NPV) concept.

The EU comparative methodology uses the life cycle cost (LCC) concept as the basis for the MS to compare their minimum energy performance requirements levels against cost optimal levels. The Article 5 of the EPBD defines cost optimal level as "the energy performance level that leads to the lowest cost during the estimated economic life cycle of a building or building element". The comparative methodology involves the following steps as defined in the EU Delegated Regulation 244/2012 [15]: (1) establishment of the reference buildings (RB) for different types of residential and service buildings, for both new and existing buildings; (2) identification of energy efficiency measures/packages for each RB; (3) calculation of the primary energy demand resulting from the application of such measures/packages to an RB; (4) calculation of the life cycle cost (global cost) in terms of the net present value (NPV). If the results of this comparison show that current minimum energy requirements are significantly less energy efficient than cost-optimal levels, then the MS are required to justify this difference. These global costs can be seen at the macro level 
(social) or at the end-user (micro) perspectives. As regards the reference building (RB), in each category, there are two methodologies for creating an RB: the $R B r$ methodology, in which a real building representing the most typical building in each category is selected; the $R B v$ methodology, which consists in the creation of a virtual building which, for each relevant parameter, includes the most commonly used materials and building systems. In the latter methodology, the relevant information is either based on expert's advice or on statistical data, or a combination of both [40]. Regarding national studies that have been developed as part of the obligations contained in the Article 5 of the recast EPBD, two sets of the Portuguese government-commissioned reports [40,40-42] used the EU comparative methodology to assess the cost-optimal levels of energy efficiency measures/packages for residential, office and hotel buildings. This notion of reference building has also been applied in studies dealing with cost-optimality of energy renovation of a particular building segment of the national stock in the EU [44-46] and for identifying the cost-optimal energy efficiency requirements according to the EU comparative methodology [47].

Other studies dealing with the cost-effectiveness of energy retrofit investments have used the building typology approach, which consists in the use of representative buildings or building types identified and classified in function of specific aspects (e.g., building use, building age, building size and climatic zone) [44]. Some of these works have dealt with residential buildings [31,48-56]. For example, Ascione et al. [56], by using a reference multi-family housing in the city of Naples, applied economic methods to select the best profitable packages of energy efficiency. They found that, for a range of available budgets from $10,000 €$ to $600,000 €$, the most proper economic budget was $300,000 €$, either by using the utopia point criterion or the comfort point criterion. Conci et al. [55], using German residential multi-family buildings in the 1950s-1970s age group as a case study, applied life cycle analysis to define a benchmark for environmental impact, expressed as global warming potential (GWP), and LCC to assess the economic impact, expressed as IRR, both assessed in a Pareto optimal method, to evaluate traditional strategies of energy renovation, and whether innovative strategies performed economically and environmentally better for this purpose. They conclude that implementing the rate of traditional strategies contributed only partially to raise the degree of certainty in reaching the energy and climate targets, and that the use of RES had a much bigger impact on the GWP balance than the choice between a standard renovation or minimal renovation of the building envelope. Regarding private office buildings, most of the studies dealing with evaluation of energy retrofitting investments consist in investigating the most economically efficient retrofit measures/packages applied to these buildings [57,58]. Pikas et al. [57] assessed the economic and energy performance building fenestration design solutions applied to an office building. The analysis also looked at alternative measures to achieve the NZEB level. They found that, for the cold Estonian climate, triple glazed argon filled windows with a small window to wall ratio and walls with $200 \mathrm{~mm}$ thick insulation are energy efficient and cost optimal within 20 years. However, they concluded that existing NZEB solutions are not cost optimal, but this should change in the near future. However, a significant number of studies have been, most recently, combining LCC analysis with environmental analysis in this building segment as well [59-61]. Gustafsson et al. [60] used as a case study a typical office building in three European climates (Nordic, Continental and Mediterranean) to assess the economic, energy and environmental impacts of energy retrofit measures/packages applied to this typical office building in three European climates (Nordic, Continental and Mediterranean). These packages included insulation, windows, energy generation and distribution systems and solar photo-voltaic, with a total of 255 renovation cases. They found that a reduction in final energy cost of up to $74 \%$ could be achieved in the Mediterranean climate, up to $77 \%$ in the Continental climate and up to $70 \%$ in the Nordic climate, compared to the reference cases. Gangolells et al. [59] presented a model for identifying environmental, cost-effective retrofitting measures by assessing their energy, economic and environmental impact when they are applied to the entire office stock. Their methodology built upon the energy performance certificate scheme to identify the life-cycle energy, economic and 
environmental impacts of a set of energy renovation measures for each representative office. They concluded that the most efficient energy renovation measures were heat pump replacement $(18.1 \%)$ and replacement of lamps with LEDs (14.4\%). However, they also found that the most effective renovation solutions depended on the evaluation criteria (energy, economic or environmental).

Studies dealing with building renovation investments have also addressed public buildings [62,63] and historical buildings [64]. Ferrari \& Beccali [62] took a building located in the campus of Politecnico de Milano (Italy) as a case study. They used the LCC and SPB methods to select the most financially efficient packages for improving the energy performance of the building toward NZEB requirements. They found that it was possible to reduce primary energy needs and associated emissions up to $40 \%$ from current values by adopting traditional and well-proven technological solutions for retrofit. They also concluded that retrofit solutions that do not include improvements on the building envelope are generally the most cost-effective options. Regarding the studies that took single family or multi-family housing in Portugal as a case study, Ferreira et al. [65] used the LCC and SPB methods to assess the most cost-effective solutions to achieve net-zero requirements, by taking a single-family housing in $\mathrm{O}^{\prime}$ Porto city as a reference. They then compared these net-zero solutions with those resulting from the cost-optimal calculation. They concluded that both approaches led to similar results, implying that the transition from cost-optimality to NZEB requirements could occur in Portugal. Tadeu et al. [66], used the LCC method to evaluate 15 alternative retrofit packages for a single-family building and an apartment in a multi-family building. Both buildings are typical of the pre-1960 age. By following the EU comparative methodology, they provided alternative procedures to identify the macroeconomic and financial solutions. They found that their results reflected the then market values better than those provided in Government national reports. Rodrigues et al. [67] took a 19th century stone masonry residential building, located in O'Porto city, as a case study, to assess the applicability of the EnerPHit standard in existing buildings. The reference solution was then studied in six climate zones in the north and center of the Portugal mainland. They founded that an energy efficiency measure consisting of an XPS solution had a discounted pay-back between 11 and 12 years, and a vacuum insulation panel solution had a discounted pay-back of more than 30 years, in all climate zones analyzed. From this review, it is reasonable to assume that most studies dealing with economic evaluation of renovation investments in Portugal have addressed the singlefamily and multi-family housing segments of the building sector. This research aims to contribute to fil the gap regarding economic studies on renovation investments pertaining to the commercial and service segment in this country.

\section{Methodology}

This research aims to explore the evaluation of energy building retrofits from a costeffectiveness approach, with reference to a single case study that is representative of a particular building cluster in Portugal. In the first step of the study, the EU and Portugal's regulatory and policies frameworks for energy efficiency of the building sector were reviewed. This included the EU's harmonized methodology for calculating cost-optimal levels of energy performance requirements, and the issues related with the staged approach to renovation. Next, a financial analysis through the NS method combined with a dynamic energy simulation was undertaken to determine the energy performance of the building, considering two alternatives: the "base building"; a set of scenarios of energy efficiency measures/packages for improving the energy performance of the building. This was followed by the analysis of the economic feasibility of the staged renovation approach to the building. The energy efficiency measures analyzed consisted of two passive technologies which applied to the building envelope and an energy-efficient domestic hot water equipment. For each of efficiency measures/packages, the following parameters were identified: initial investment cost; operation and maintenance cost; the equipment's residual values at the end of the period of analysis; incurred savings. These savings were 
calculated as the difference between the energy consumption of different energy vectors (electricity and natural gas) of the "base building" and that of the building implement with different energy efficiency measures/packages. The study period was set at 30 years.

The next subsections present: (i) the building characteristics, the climate conditions and the proposed retrofit actions to be applied to the building (Section 3.1); (ii) the dynamic energy simulation of the building (Section 3.2); (iii) the key data and assumptions of the life cycle financial analysis (Section 3.3).

\subsection{Case Study Building and Retrofit Actions \\ 3.1.1. Building Characteristics and Climate}

The building under study is part of a building complex, constructed in 1933, and is located in the town center of Bragança, Portugal, at an altitude of $656 \mathrm{~m}$ and a distance to the coast of about $173 \mathrm{~km}$. The premise, which is owned by a Catholic Church's organization, has a U-shaped configuration (Figure 1a), in which the left wing (building A) has been functioning as a church and the right wing (building B) has been used both as a primary and secondary levels school and residence for boarding students. The central wing (building C), had also been used as a student residence until the 1990's and has been, since then, unoccupied and in a degraded conservation status. The architecture of the building $\mathrm{C}$, which is object of the present study, consisted, originally, of granite stone masonry walls (in Portugal, buildings built before the Second World War have, generally, a load-bearing wall, in which the structure and the envelope are coextensive), floor slabs with a wooden-framed structure and wooden flooring, and partition walls comprising a wooden-grid structure filled and covered with earth-based mortar. The roof consisted of a wooden structure covered with ceramic tiles and the windows had single glasses, equipped with a wooden frame. The building is $48 \mathrm{~m}$ wide, Southwest-Northeast, and $12.4 \mathrm{~m}$ long, Northwest-Southeast, with its main façade facing Southeast (Figure 1b).

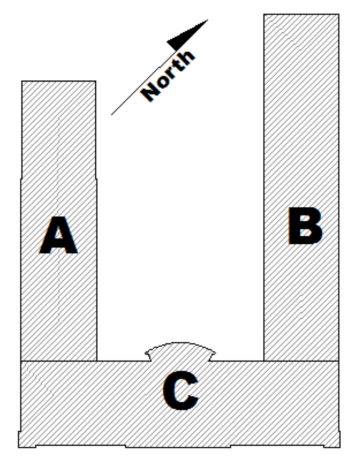

(a)

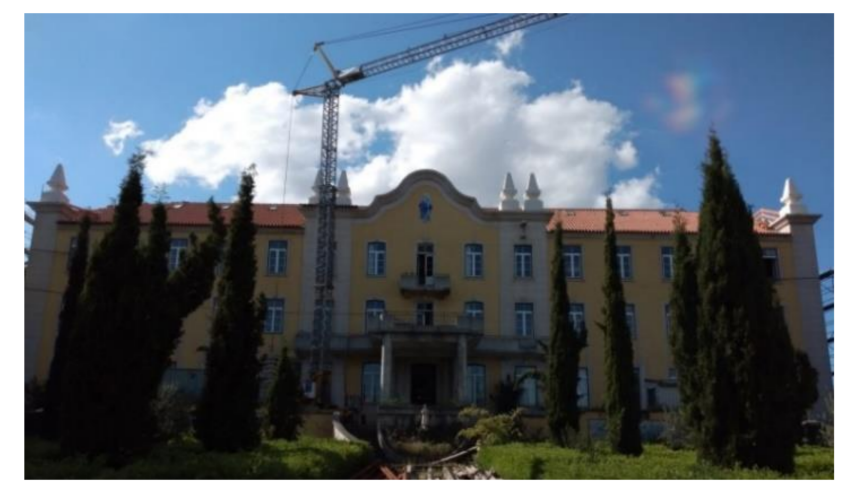

(b)

Figure 1. (a) Sketch of the building complex plan; (b) main façade of the central wing (C).

The building is not yet renovated but the project design was recently developed. The owner's objective was to provide the building with adequate conditions of habitability, including the eventual improvement of its energy performance. The project design consists of the preservation of the external walls, the erection of a reinforced concrete pillar-beams frame structure in the interior of the building, replacement of the wooden-framed ceilings with precast reinforced concrete slabs in the floors. The double-glazed windows, equipped with an aluminum frame, that replaced the original windows, were also preserved. The building has a partial underground floor, a light-colored exterior surrounding, spreading over three floors above ground level and the attic, with vertical connection bridged by stairs. The total gross area of the building is $2665.60 \mathrm{~m}^{2}$, of which $1521.30 \mathrm{~m}^{2}$ are heated area; the exterior wall area is $1275.67 \mathrm{~m}^{2}$; the pitched roof area is $670.89 \mathrm{~m}^{2}$ (Table 1). 
Table 1. Building areas $\left(\mathrm{m}^{2}\right)$.

\begin{tabular}{cc}
\hline Basement & 370.00 \\
Ground floor & 595.20 \\
First floor & 595.20 \\
Second floor & 595.20 \\
Attic & 510.00 \\
Total gross floor area & 2665.60 \\
Total heated area & 1521.30 \\
Exterior glazed area & 211.99 \\
Exterior walls area (excluding glazed area) & 1275.67 \\
Skylight area on the pitched roof & 11.00 \\
Walls area in contact with the ground & 83.50 \\
Flat roof area (adjacent staircase) & 51.00 \\
Pitched roof area & 670.89 \\
\hline
\end{tabular}

The thermal characterization of the building envelope, namely the building parameters and the thermal transmittance coefficient of the walls and roof was performed according to the Ministerial Decision $n^{\circ} 15793-E / 2013$ [68]. This legal provision established a simplified procedure to be used in service buildings undergoing major renovations, as well as in existing buildings. The reference publication ITE 50 from the Portuguese National Laboratory for Civil Engineering [69] provides the reference values for all building elements, such as glazing and outer covering. Regarding the glazing, two different types were observed: glazing 1-aluminum frame, with double glasses $6 \mathrm{~mm}+6 \mathrm{~mm}$, with $16 \mathrm{~mm}$ air box, without sun protection; glazing 2-aluminum frame, with double glasses $6 \mathrm{~mm}+6 \mathrm{~mm}$, with $16 \mathrm{~mm}$ air box, with interior sun protection composed of a wooden board. The thermal transmittance coefficient and solar glass factor of the two types of glazing are presented in Table 2.

Table 2. Thermal transmittance coefficient and solar glass factor of the glazing.

\begin{tabular}{cccc}
\hline Glazing Type & $\begin{array}{c}\text { Thermal Transmittance } \\
\text { Coefficient } \mathbf{U}\left(\mathbf{W} / \mathbf{m}^{\mathbf{2}}{ }^{\circ} \mathbf{C}\right)\end{array}$ & Solar Glass Factor & $\begin{array}{c}\text { Solar Glass Factor with } \\
\text { Protection }\end{array}$ \\
\hline GL1 & 3.8 & 0.75 & - \\
GL2 & 3.1 & 0.75 & 0.46 \\
\hline
\end{tabular}

The characteristics of the opaque envelope elements of the renovated building are as follows:

- External wall: consists of granite stone masonry with a thickness of $95 \mathrm{~cm}$ with $2.5 \mathrm{~cm}$ thick cement plaster on both sides, resulting in a thermal transmittance coefficient of $1184 \mathrm{~W} / \mathrm{m}^{2}{ }^{\circ} \mathrm{C}$;

- Roof: consists of a wooden structure covered with ceramic tiles, resulting in a thermal transmission coefficient of $1.30 \mathrm{~W} / \mathrm{m}^{2}{ }^{\circ} \mathrm{C}$.

Climate zoning in Portugal is presented at the Level III of the Nomenclature of Territorial Units for Statistical Purposes (NUTS). Its composition by municipality is detailed in the Ministerial Decision $n^{\circ} 15793-\mathrm{F} / 2013$ [70]. The building under study is located in Bragança, which corresponds to the NUTS III Alto Trás-os-Montes. Applying the Equations (1) and (2), as described in the Ministerial Decision $n^{\circ} 15793-F / 2013$, the climate zone of the building was determined.

$$
H D D=H D D_{r e f}+a\left(z-z_{r e f}\right),
$$

where $H D D_{r e f}$ is the reference heating degree day, on the basis of $18^{\circ} \mathrm{C}$, corresponding to the conventional heating season of $2015^{\circ} \mathrm{C}, a$ is the slope for altitude adjustments, $1400{ }^{\circ} \mathrm{C} / \mathrm{km}, z$ is the altitude of the building location, $656 \mathrm{~m}$, and $z_{\text {ref }}$ is the reference altitude 
of $680 \mathrm{~m}$. The resulting value is $1981.4^{\circ} \mathrm{C}$, which corresponds to zone W3 according to Table 3.

$$
\theta_{\text {ext }, v}=\theta_{\text {ext,vref }}+a\left(z-z_{\text {ref }}\right)
$$

where $\theta_{\text {ext,vref }}$ is the reference outdoor temperature corresponding to the conventional cooling season, $21.5^{\circ} \mathrm{C}$, $a$ is the slope for altitude adjustments, $-4{ }^{\circ} \mathrm{C} / \mathrm{km}, z$ is the altitude of the building location, $656 \mathrm{~m}$, and $z_{\text {ref }}$ is the reference altitude of $680 \mathrm{~m}$. The resulting value is $21.60{ }^{\circ} \mathrm{C}$, which corresponds to zone S2 according to Table 4.

Table 3. Criterion for determining the winter climate zone.

\begin{tabular}{ccccc}
\hline Criterion & $H D D \leq 1300$ & $\mathbf{1 3 0 0}<$ HDD $\leq \mathbf{1 8 0 0}$ & HDD $>1800$ \\
Zone & W1 & W2 & W3 & \\
\hline
\end{tabular}

Table 4. Criterion for determining the summer climate zone.

\begin{tabular}{cccc}
\hline Criterion & $\theta_{\text {ext }, v} \leq \mathbf{2 0}{ }^{\circ} \mathbf{C}$ & $\mathbf{2 0}{ }^{\circ} \mathbf{C}<\theta_{\text {ext,v }} \leq \mathbf{2 2}{ }^{\circ} \mathbf{C}$ & $\theta_{\text {ext,v }}>\mathbf{2 2}{ }^{\circ} \mathbf{C}$ \\
\hline Zone & $\mathrm{S} 1$ & $\mathrm{~S} 2$ & $\mathrm{~S} 3$ \\
\hline
\end{tabular}

\subsubsection{Regulatory Framework and Retrofit Actions}

Energy performance of service buildings in Portugal is regulated by the Decree/Law $\mathrm{n}^{\mathrm{o}}$ 101-D/2020 [71], which is a transposition of the 2018 EPBD. This normative document requires that new buildings (from 2021 onwards all new buildings must have NZEB requirements) and building undergoing major renovations shall present a minimum level of energy performance requirements. These requirements must take in to account the climatic characteristics of the zone where the building is located. In the case of building interventions that do not reach the threshold of "major renovation" stated in the legislation, the installed/retrofitted building components are only required to have a minimum energy performance level. In these situations, as it is the case of this intervention, it was up to the design team to provide design options that best suited the building characteristics. The energy-related design solutions for the base building scenario and those for the energy efficiency measures were the results of interactions between the design team and one of the co-authors of this study. As it is usual in practice, the available budget represented a constraint regarding investment costs. Thus, the design consultants devised a "base building" scenario for the building technical systems comprised of: (i) heating system-a natural gas condensing boiler with continuous operation, with a nominal efficiency of $105.1 \%$, according to the document presented by the equipment supplier. This value is higher than the regulatory minimum requirement (96\%) set in the Portuguese legislation; (ii) domestic hot water (DHW) system-a set of gas-fired water heaters placed in strategic points in the building; (iii) lighting system-LED lamps in all areas of the building; (iv) cooling systemcooling fans in all bedrooms and social areas. The actual glazing system was preserved because it presented an adequate conservation status and its replacement with a more energy efficient one would not fit in the available budget. The exterior façade of the building was also preserved, owing to aesthetic considerations. This constraint to façade modification entailed the selection of alternative energy retrofitting choices instead of external insulation, as it happens, generally, in interventions in historical buildings [31]. The design options also had to comply with the Portuguese legislation regarding the maximum values for thermal transmittance coefficients, as stated in the Ministerial Decision $\mathrm{n}^{\mathrm{o}}$ 15793-E/2013 [68], and as amended in the Ministerial Order 138-I/2021 [72]: vertical opaque elements $\left(U=0.50 \mathrm{~W} / \mathrm{m}^{2}{ }^{\circ} \mathrm{C}\right)$; horizontal opaque elements $\left(U=0.40 \mathrm{~W} / \mathrm{m}^{2}{ }^{\circ} \mathrm{C}\right)$; glazing system $\left(U=3.30 \mathrm{~W} / \mathrm{m}^{2}{ }^{\circ} \mathrm{C}\right)$. The energy efficiency measures proposed for the building energy retrofitting were as follows:

- Installation of internal insulation of the roof, by means of installation of $10 \mathrm{~cm}$ thick cork-based panels $\left(I_{r}\right)$; 
- Installation of internal insulation of the vertical envelope, by means of installation of $10 \mathrm{~cm}$ rockwool panels $\left(I_{v}\right)$;

- Installation of an aerothermal heat pump for the DHW system $(H P)$ as an alternative to the set of gas-fired water heaters. According to the document presented by the equipment supplier, the COP of the aerothermal heat pump is 3.5, which is higher than the regulatory minimum requirement.

The temperature set points for heating and cooling were, respectively, $20^{\circ} \mathrm{C}$ and $25^{\circ} \mathrm{C}$.

\subsection{Building Energy Modelling}

EnergyPlus, which is a program accredited by ASHRAE Standard 140 was the energy simulation tool used in the study. In the simulation, the following data were collected for each room: type of space; the average occupation rate and the average utilization rate; the power capacity of lighting systems and their operation schedule; the heating and cooling systems and their operation schedule. To run several simulations needed to assess the energy performance of the "base building" and that of the building implemented with each one of the energy efficiency measures, it was necessary to create a 3D building model in the DesignBuilder, which is a graphical user interface of EnergyPlus. The 3D model was intended to represent the actual building operating conditions as well as their construction characteristics, which makes the simulation as reliable as possible [73]. After properly treating the building plans by using the AutoCAD software, the plans were exported to the DesignBuilder. After drawing the contours of each slab, creating blocks and overlapping them to shape the building, the glazed spans were then created. Figure $2 a, b$, show, respectively, the 3D model of the first floor and the 3D model of the envelope. In the 3D model, each floor was divided into zones according to the Ministerial Order $\mathrm{n}^{\circ}$ 349-D/2013 [74] for multi-zone simulations. It was also necessary to characterize each area according to its use, occupation and illuminance.

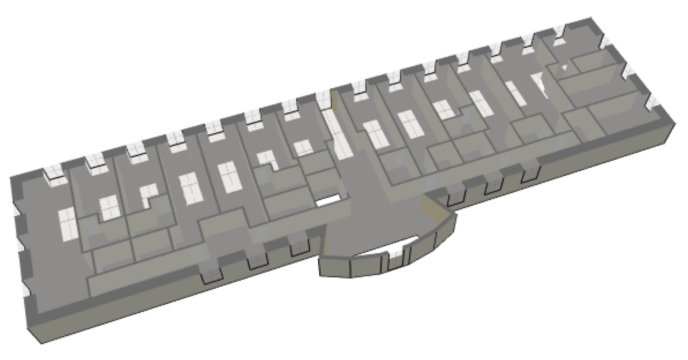

(a)

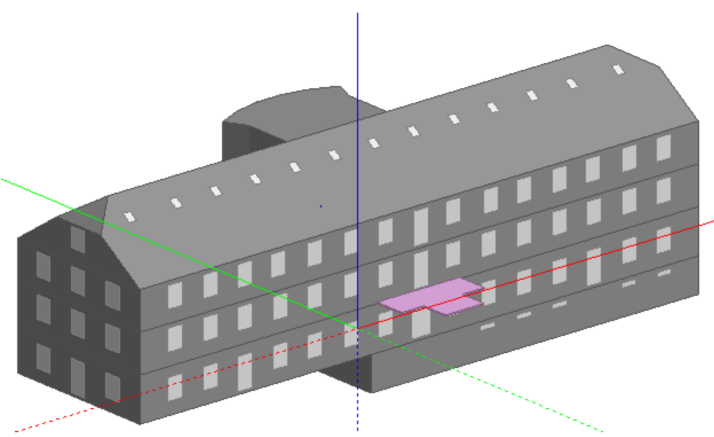

(b)

Figure 2. (a) Model of the first floor; (b) model of the building envelope.

The modelling of the building by construction elements is shown in the software in different colors (Figure 3a). Figure $3 b$ shows the set of the building surroundings, shading and other details. The shading is represented according to daytime and month of the year. 


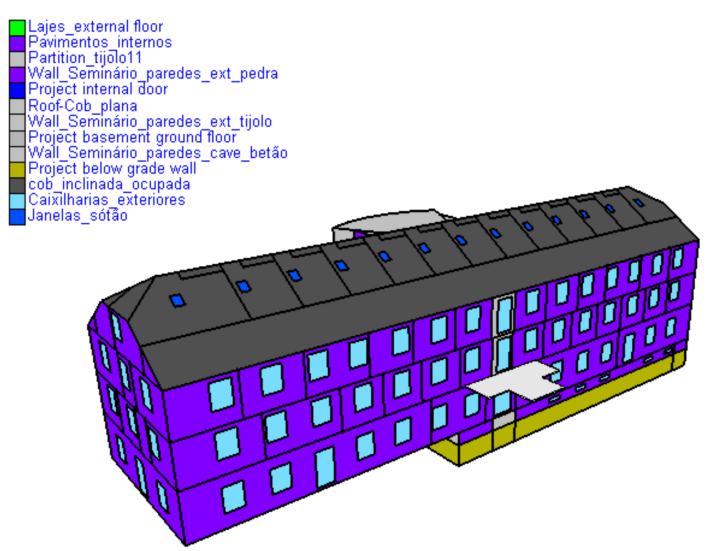

(a)

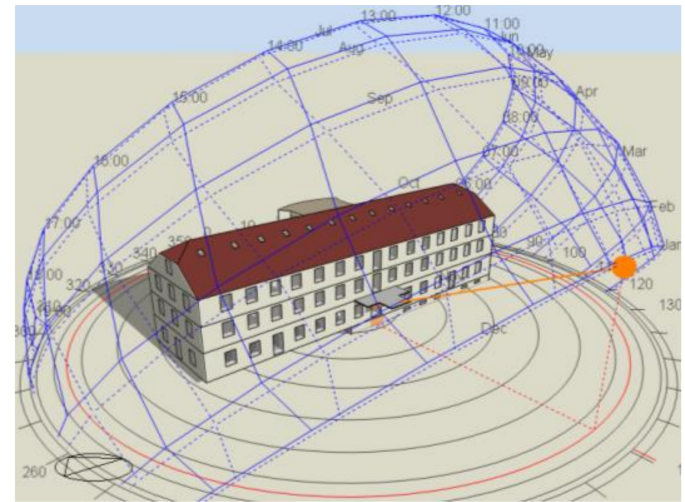

(b)

Figure 3. (a) Building modelling by construction elements; (b) 3D model of the building in view mode.

\subsection{Life Cycle Financial Analysis-Key Data and Assumptions}

\subsubsection{Method of Analysis and Selection of Interest Rates}

As already mentioned, the EU comparative methodology adopts the LCC method to choose the least global costs of different energy efficiency measures/packages. This is conducted to set up minimum energy performance requirements at the national scale. Either the NS method or the IRR method could be applied to assess the financial viability of the proposed interventions. The IRR measures the percentage yield of an investment. It is then compared against the investor's minimum acceptable rate of return (or reasoned by the average long-term capital market interest rates) to ascertain the economic/financial attractiveness of the investment. As stated earlier, the use of these methods is usually coupled with the use of the SPB method, which is usually adopted as a pre-test of the financial efficiency of each of the retrofit measures (see Section 4.2). The SPB method measures how long it takes to recover investment costs. As a rule of thumb, an investment that has both an SPB shorter than the economic life of the building and the useful life of the building system generally signals an economic investment, setting aside the time value of money [37]. Otherwise, it should be rejected. Some authors [55,73] have argued that, at the private investor's perspective, the IRR method is more informative. However, this study is not only concerned with the financial attractiveness of an investment per se. It also attempts to encapsulate the societal perspective of a private investment, i.e., its contribution to the country's energy and climate goals. Thus, what is considered here is whether an energy efficiency measure/package has a positive net saving at the end of the building study period as well as being conductive to a significant reduction in primary energy consumption. The NS formula is presented in Equation (3).

$$
P V N S_{A 1: A 2}=\sum_{t=0}^{N} \frac{S_{t}-\left(I_{t}+M_{t}+R p_{t}\right)+R V_{N}}{(1+D)^{t}},
$$

where $P V N S_{A 1: A 2}$ - present value of net savings of alternative $A_{1}$ when compared with a mutually exclusive alternative $A_{2}, S_{t}$-savings in year $t$ of $A_{1}$ less those of $A_{2}, I_{t}$ investment costs in year $t$ of $A_{1}$ less those of $A_{2}, M_{t}$-operation and maintenance costs in year $t$ of $A_{1}$ less those of $A_{2}, R p_{t}$-replacement costs in year $t$ of $A_{1}$ less those of $A_{2}$, $R V_{N}$-residual value in year $N$ of the study period of $A_{1}$ less that of $A_{2}, N$-number of years in the study period and $D$-discount rate.

The NS formula can be reduced to a difference between the life cycle costs of the two alternatives, where $A_{2}$ corresponds to the "base building" scenario and $A_{1}$ to the "base 
building" implemented with energy efficiency measures/packages. The formulae are presented in Equations (4) and (5).

$$
\begin{gathered}
\operatorname{PVLCC}_{A 1}=\sum_{t=0}^{N} \frac{\left(I_{t}+M_{t}+R p_{t}\right)+\text { Ener }_{t}-R V_{N}}{(1+D)^{t}} \\
P V L C C_{A 2}=\sum_{t=0}^{N} \frac{\text { Ener }_{t}}{(1+D)^{t}}
\end{gathered}
$$

where $E n e r_{t}$ is annual energy costs in year $t$.

If $P V L C C_{A 1}<P V L C C_{A 2}$, the NS is positive, which signals an investment that is economically efficient. As can be deducted from the above formulae, discount rates are a crucial economic parameter in energy system analysis [18,75]. Indeed, the trickiest aspect of the EU comparative methodology is the choice of the discount rate. It is usually set up in real terms i.e., not considering inflation throughout the economic life of the building/building system. At the macro level, it depends on a country's macroeconomic fundamentals as well as on the interest rates set up by national central banks or by the European Central Bank. At the micro level, it tends to reflect the conditions of the market price of capital. Within this concept, the discount rate at the perspective of a private non-commercial investors is, usually, lower than that of a property investor [76]. Steinbach and Staniaszek [75] and Hermelink and de Jager [77] provided a review of the discount rates prevailing in some European countries and US, at both macro level and micro level perspectives. Steinbach and Staniaszek [75] found that social discount rates in the MS national reports were set up in a range between $1 \%$ and $7 \%$, as measured in real terms. For private non-commercial and non-industrial investors, including the household sector, the authors recommended a real discount rate in a range between $3 \%$ and $6 \%$. In the Annex 1 of the EU Cost-Optimality Delegated Regulation, it is set that Member States "have to determine the discount rate to be used in the macroeconomic calculation after having performed a sensitivity analysis on at least two different rates, one of which shall be 3\% expressed in real terms" [15]. The Portuguese national report [43] used real discount rates of $3 \%$ and $1.5 \%$ in the sensitivity analysis, for both the macroeconomic and financial calculations. As the building owner's organization is a non-commercial private investor, an estimation of the discount rate tends to come near of the lower tier of Steinbach and Staniaszek's [75] discount rate range. However, a more recent study dealing with the energy renovation of the national building stock in Portugal [34] used a nominal discount rate of $2.52 \%$ for the financial analysis. We do believe that this strikingly low discount rate ( $1 \%$ in real terms) is illustrative of the Portuguese authorities' strong commitment in tackling energy consumption in buildings and, ultimately, in dealing with the issues related with the climate crisis. However, this discount rate used in the latter study also seems to reflect the positive climate of low interest rates and low inflation that prevailed in Portugal and in the EU throughout the last decade. Data drawn from the Pordata database [78] indicated that the average mortgage interest rate in Portugal in the period 2011-2020 was $2.39 \%$ (average for the period) and the average annual inflation rate, as measured by the Consumer Price Index, was $1.52 \%$ in the same period [34]. Thus, real discount rates of 3\% and $1 \%$ were used in the sensitivity analysis in this study. The study period was set at 30 years, ending in 2050.

\subsubsection{Costs and Useful Lives of the Retrofit Measures}

The global costs of the retrofit actions were calculated according to the methodology described in the Commission Delegate Regulation (EU) 244/2012 [15]. They were calculated as the sum of the present value of the investment costs, running costs and replacement costs, as well as disposal costs if applicable. In some situations, the investment costs are calculated as extra-investment costs i.e., the investment cost of a specific retrofit action minus the investment costs that would incur in the "base building" scenario if the retrofit action was not implemented. As it is usual in this kind of financial analysis, the maintenance 
and operation costs that occur in all considered alternatives (including the "base building" one) were not taken in consideration. The useful lives of $I_{r}$ and $I_{v}$ were set at 30 years, so no residual value was considered for these retrofit measures. For HP (aerothermal heat pump), the useful life was set at 20 years and the residual value was calculated by using the linear depreciation method. The annual maintenance and operation costs of $H P$ were set at $2 \%$ of the investment cost. The cost of the design solutions for the envelope were taken from Cype Ingenieros database [79]. The cost of the vertical insulation (including gypsum board) is $44.78 € / \mathrm{m}^{2}$. From this value, $6.00 € / \mathrm{m}^{2}$ was deducted, which is the cost of the wall covering pertaining to the "base building" scenario. The cost of the roof insulation is $35.59 € / \mathrm{m}^{2}$. Again, from this value, $4.00 € / \mathrm{m}^{2}$ was deducted, which is the cost of the attic ceiling finishing pertaining to the "base building" scenario. The cost of the heat pump was taken from equipment suppliers-12,510.78 $€$. From this value, $5510 €$ was deducted (10 electric radiators), which is the alternative investment cost for the "base building" scenario. Table 5 presents the extra-investment costs of these energy retrofitting options.

Table 5. Investment cost of the energy efficiency measures.

\begin{tabular}{cc}
\hline Type of Energy Efficiency Measure & Extra-Investment Cost $(\boldsymbol{€})$ \\
\hline Internal insulation of the roof $\left(I_{r}\right)$ & $20,844.55$ \\
Internal insulation of the vertical envelope $\left(I_{v}\right)$ & $49,470.48$ \\
Aerothermal heat pump $(H P)$ & 7000.78 \\
\hline
\end{tabular}

\subsubsection{Energy Prices Development}

In the Portuguese national report [43] to comply with the Article 5 of the EPBD recast, three scenarios of energy price development were modelled: (i) "high price" scenario-an escalation annual rate of $2 \%$; (ii) "medium price" scenario-an escalation annual rate of $1 \%$; (iii) "low price" scenario with constant prices throughout the study period. These escalations rates were expressed in real terms. As regards the relation between discount rates and escalation rates of energy prices, it is worth noting that, in the rationale of economic evaluation, the present value of net savings in energy costs decreases with increasing time along the study period if the discount rate is higher than the growth rate of energy prices, both expressed in real terms. This research followed previous works [55,73], that adopted constant (in real terms) energy prices along the study period to account for the volatility in the energy market. Energy prices were taken from the Pordata database [78]. The average prices of electricity and of natural gas in 2020 were, respectively, $0.2246 € / \mathrm{KWh}$ and $0.0776 € / \mathrm{KWh}$, and it was assumed that these prices will remain the same for 2021, the beginning of the study period.

\section{Results and Discussion}

\subsection{Energy Simulation Results}

Table 6 presents the annual final energy consumption of the "base building" by type of technical system. It also shows the total final energy consumption by type of energy vector: natural gas (NG); electricity (E).

Table 6. Final energy consumption of the "base building" by type of technical system (Kwh).

\begin{tabular}{cc}
\hline Lighting & $21,222.24$ \\
Equipment & $24,899.23$ \\
Cooling & 1319.47 \\
Heating & $127,107.04$ \\
Domestic hot water (DHW) & $43,898.74$ \\
Total consumption-natural gas (NG) & $171,005.74$ \\
Total consumption-electricity (E) & $47,440.94$ \\
\hline
\end{tabular}

Table 7 presents the annual final energy consumption of the building implemented with each of the following energy efficiency measures: (i) installation of internal insu- 
lation of the roof $-I_{r}$; (ii) installation of internal insulation of the vertical envelope $-I_{r}$; (iii) installation of an aerothermal heat pump for the DHW system-HP. Again, it also shows the total final energy consumption by energy vehicle: NG; E. Note that the calculations refer to the final energy consumption of the "base building" implemented with different energy retrofitting measures. In the case of $H P$, the heat pump is an alternative of the set of gas-fired water heaters for the DHW system.

Table 7. Final energy consumption of the "base building" implemented with each of the efficiency measures $I_{r}, I_{v}$ and $H P$ (Kwh).

\begin{tabular}{|c|c|c|c|}
\hline & $I_{r}$ & $I_{v}$ & $H P$ \\
\hline Lighting & $21,222.24$ & $21,222.24$ & $21,222.24$ \\
\hline Equipment & $24,899.23$ & $24,899.23$ & $24,899.23$ \\
\hline Cooling & 1319.47 & 1319.47 & 1319.47 \\
\hline Heating & $114,670.00$ & $101,798,21$ & $127,107.04$ \\
\hline Domestic hot water (DHW) & $43,898.74$ & $43,898.74$ & $11,635.81$ \\
\hline Total consumption-natural gas (NG) & $158,568.74$ & $145,696.95$ & $127,107.04$ \\
\hline Total consumption-electricity (E) & $47,440.94$ & $47,440.94$ & $59,076.75$ \\
\hline
\end{tabular}

\subsection{Financial Evaluation of Energy Retrofit Investments}

As can be constructed from Table 5, seven different options of energy efficiency measures/packages were analyzed. These are, in an ascending order of investment costs (note that for $\mathrm{HP}$, the investment cost of the gas-fired water heaters, which amounted to $5510 €$, was deducted from the cost of the heat pump): $H P\left(\mathrm{~B}_{1}\right) ; I_{r}\left(\mathrm{~B}_{2}\right) ; H P+I_{r}\left(\mathrm{~B}_{3}\right) ; I_{v}\left(\mathrm{~B}_{4}\right)$; $H P+I_{v}\left(\mathrm{~B}_{5}\right) ; I_{r}+I_{v}\left(\mathrm{~B}_{6}\right) ; H P+I_{r}+I_{v}\left(\mathrm{~B}_{7}\right)$. The SPB method was used as a pre-test for assessing the financial efficiency of the energy retrofit measures/packages. The annual savings were calculated from the data presented in Tables 6 and 7.

Table 8 presents the investment costs, annual savings and the payback times of the efficiency measures/packages $B_{1}$ to $B_{7}$. It shows that $B_{1}$ (installation of heat pump), with an SPB of 10.48 , is the most financially efficient option, followed by option $B_{3}$ (installation of heat pump plus installation of roof insulation), with an SPB of 17.05 years. The least financially efficient retrofit option is $\mathrm{B}_{4}$ (internal insulation of the vertical envelope) with an SPB of 25.19 years, followed by the packages that include both $I_{r}$ and $-\mathrm{B}_{6}$ and $\mathrm{B}_{7}-$ with payback times of, respectively, 24.49 and 24.00 years.

Table 8. Investment costs, annual savings and SPB of the efficiency measures/packages $B_{1}$ to $B_{7}$.

\begin{tabular}{cccc}
\hline $\begin{array}{c}\text { Energy Efficiency } \\
\text { Measures/Packages }\end{array}$ & Investment Cost & Annual Cost Savings (€) & SPB (Years) \\
\hline$B_{1}$ & 7000.78 & 668.03 & 10.48 \\
$B_{2}$ & $20,8844.55$ & 965.11 & 21.60 \\
$B_{3}$ & $27,845.33$ & 1633.14 & 17.05 \\
$B_{4}$ & $49,470.48$ & 1963.97 & 25.19 \\
$B_{5}$ & $56,471.26$ & 2632.00 & 21,46 \\
$B_{6}$ & $70,315.03$ & 2929.08 & 24.49 \\
$B_{7}$ & $77,315.81$ & 3597.11 & 24.00 \\
\hline
\end{tabular}

Table also shows that all energy retrofit options have a payback time shorter than the study period. Thus, these efficiency measures/packages were further evaluated more thoroughly through the NS method. As stated before, the discount rates used in the analysis were $1 \%$ and $3 \%$. By using the data presented in Tables 6 and 7 , the life cycle costs of the retrofit options (including that of the "base building") were calculated by applying the Equations (4) and (5). Figure 4 presents the LCCs of the "base building" and of this implemented with each of the energy efficiency measures/packages. 


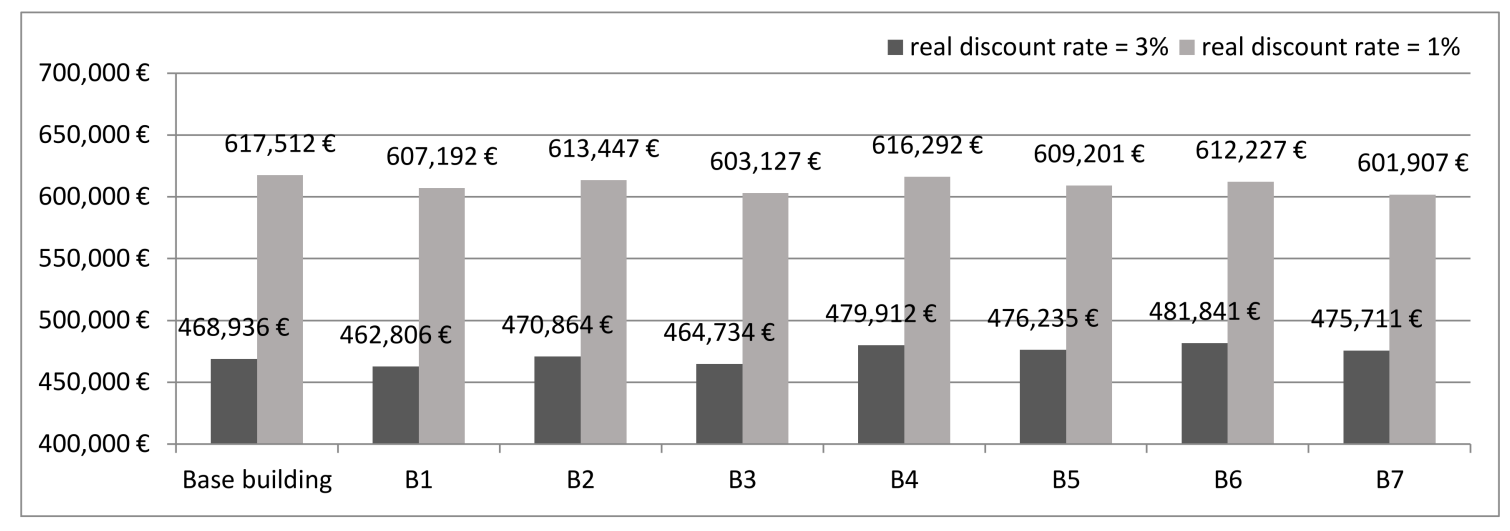

Figure 4. Global costs (LCC) of the base building and of the retrofit options $B_{1}$ to $B_{7}$.

The results presented in Figure 4 show that the financial efficiency of the retrofit options evaluated through the NS method is very sensitive to the discount rate used in the analysis. The discount rate is connected with the real or presumed cost of capital. The cost of capital is of critical importance for determining the financial attractiveness of capital-intensive investments, such as building renovation. Due to the effects of compound interests, the cost capital has increasing significance for long-term, capital-intensive investments [80]. By using the real discount rate of 3\%, the profitable retrofit measures/packages are options $B_{1}$ and $B_{3}$ only, with NS of, respectively, $6129 €$ and $4201 €$. These financial results are relatively high, considering the low values of investment costs. These figures also demonstrated that it is financially efficient to install a retrofit measure package, considering an annual real interest of $3 \%$. This corresponds to a nominal interest rate of $4.52 \%$, which is much higher than the mortgage interest rates that prevailed throughout the last decade. With a real discount rate of $1 \%$, all retrofit options are financially efficient. This corroborates the results of earlier studies $[55,62,66,73]$ that found that the lower the interest rates used in energy renovating investments the higher the financial results tend to be. By using the latter discount rate, the most profitable options depend upon the available budget. For an additional budget of 50,000 $€$, the most financially efficient options are B3 followed by $B_{1}$ (NS of, respectively, 14,385 $€$ and 10,320 $€$ ). For an additional budget of $80,000 €$, the most profitable retrofit options are $\mathrm{B}_{7}(\mathrm{NS}=15,604 €)$ followed by $\mathrm{B}_{3}$. The least economically efficient investment is $B_{4}$ for both considerations of the available budget (NS $=-10,977 €$ and $1219 €$, by using the real discount rates of, respectively, $3 \%$ and $1 \%$ ). The conjugation of the financial attractiveness of the retrofit investments and their impact on primary energy consumption of the building will be presented in the next subsection.

\subsection{Primary Energy Reduction and Economic Feasibility of the Building's Staged Renovation}

The efficiency of energy renovation investments can also be seen at a macroeconomic (social) perspective i.e., reduction in energy consumption. In the life cycle energy analysis, the form of energy must be clarified. The energy used by the consumer is known as delivered energy or final energy. However, a considerable amount of energy is spent in the production of the delivered energy, and it varies according to energy vector (e.g., natural gas or electricity) and the means of producing the energy. Thus, primary energy consumption is the standard measure for assessing the energy efficiency strategy of an economy or a sector. Primary energy factors (PEF) are used for converting final energy into primary energy. In Portugal, according to the Ministerial Decision n ${ }^{\circ} 15793-D / 2013$ [74,81], the PEF for electricity is $2.5 \mathrm{Kwhpe} / \mathrm{Kwh}$ and that of natural gas is $1 \mathrm{Kwhpe} / \mathrm{Kwh}$. Table 9 presents the annual final energy consumption by type of energy vector and total primary energy consumption for both the "base building" and of this implemented with the energy retrofit options. 
Table 9. Final energy consumption, primary energy consumption and reduction in primary energy consumption of the retrofit options $B_{1}$ to $B_{7}$.

\begin{tabular}{|c|c|c|c|c|}
\hline \multirow{2}{*}{$\begin{array}{l}\text { Energy Retrofit } \\
\text { Option }\end{array}$} & \multicolumn{2}{|c|}{ Final Energy Consumption (Kwh) } & \multirow{2}{*}{$\begin{array}{c}\text { Primary Energy } \\
\text { Consumption (Kwhpe) }\end{array}$} & \multirow{2}{*}{$\begin{array}{c}\text { Reduction in Primary } \\
\text { Energy Consumption (\%) }\end{array}$} \\
\hline & NG & $\mathrm{E}$ & & \\
\hline Base building & $171,005.78$ & $47,440.94$ & $289,608.13$ & - \\
\hline $\mathrm{B}_{1}$ & $127,107.04$ & $59,076.75$ & $274,798.92$ & 5.11 \\
\hline $\mathrm{B}_{2}$ & $158,568.74$ & $47,440.94$ & $277,171.09$ & 4.29 \\
\hline $\mathrm{B}_{3}$ & $114,670.00$ & $59,076.75$ & $262,361.88$ & 9.41 \\
\hline $\mathrm{B}_{4}$ & $145,696.95$ & $47,440.94$ & $264,299.30$ & 8.74 \\
\hline $\mathrm{B}_{5}$ & $101,798.21$ & $59,076.75$ & $249,490.09$ & 13.85 \\
\hline $\mathrm{B}_{6}$ & $133,259.91$ & $47,440.94$ & $251,862.26$ & 13.03 \\
\hline $\mathrm{B}_{7}$ & $89,361.17$ & $59,076.75$ & $237,053.05$ & 18.14 \\
\hline
\end{tabular}

Table 9 shows that the most efficient retrofit option for improving the energy performance of the building, at an environmental point of view, is, as was expected, $\mathrm{B}_{7}$, which is the package that includes all energy efficiency measures $\left(H P+I_{r}+I_{v}\right)$, with a primary energy consumption reduction of $18.14 \%$. This is followed by the retrofit options that include $I_{v}\left(\mathrm{~B}_{5}\right.$ and $\left.\mathrm{B}_{6}\right)$, with primary energy consumption reductions of, respectively, $13.85 \%$ and $13.03 \%$. For all these retrofit options, the additional budget considered was $80,000 €$. Considering an additional budget of 50,000 $€$, the most environmentally efficient option ( $9.41 \%$ in primary energy reduction) was $\mathrm{B}_{3}$, which also is the most financially efficient option. Conjugating these results with those of the preceding subsection, the following ranking of the above-mentioned energy retrofit options has been inferred:

- Basic package, and thus a combination of internal insulation of the roof with the installation of an aerothermal heat pump for the domestic hot water system;

- Installation of internal insulation of the vertical envelope.

Finally, the design team should select the retrofit measures, depending on the available budget, according to the shown priority.

One way to assess the energy efficiency of a building retrofit investment is to compare the reduction in primary energy consumption with the investment-to-the-buildingconstruction-cost ratio. The EPBD (and the Portuguese legislation) do not provide thresholds for energy renovations in buildings. Nor do they define what constitute light (minor) and medium (moderate) renovations [73]. Major renovations, as defined in the EPBD recast, are interventions in a building where the investment cost relating to the building systems and/or the building envelope is higher than $25 \%$ of the value of the building, excluding the value of the land. In order to compare the outcome of different renovations measures between EU Member countries, the EU ZEBRA2020 project [82] developed the indicator of "major renovation equivalent" and assumed that, with major renovations, a building's final energy demand for heating could be reduced by 50 to $80 \%$ (range depending on the country and according to the current efficiency of the building stock). Following Cova et al. [73], an energy retrofit investment is efficient, at the macro level, perspective, when the value of primary energy reduction (in percentage terms) is at least double than the investment-to-the-building-construction-cost ratio, also measured in percentage terms. Building construction costs for tax purposes in Portugal, for the year 2021, are $492 € / \mathrm{m}^{2}$ [83]. The total gross area of the building is $2665.60 \mathrm{~m}^{2}$. Thus, the building construction cost amounted to 1,311,475.20 $€$; Note that this figure is somewhat undervalued as the building is located in a prestigious area in the Bragança town center. Considering the retrofit package $\mathrm{B}_{7}$, the primary energy consumption reduction was $18.14 \%$ and the additional investment cost was $77,315.81 €$. The investment-to-the-building-construction-cost ratio was $5.9 \%$, or just under one-third of the value of the primary energy consumption reduction.

As regards the economic feasibility of the building's staged renovation, the aim here is not a comparison of the global costs between the two approaches-one-step deep renovation versus staged renovation-throughout the entire study period. We are of the 
view that it is not reasonable to assume in advance the prices of efficient energy generating technologies that will occur in a medium to long-term horizon, and compare them with the prices of existing technologies. Furthermore, as mentioned earlier, most of building retrofit works in Portugal and in the EU have been in the light to medium rage [14,26] and the motivations for undertaking most of these works (as in the case of this building) have not been related with energy savings. Thus, the right comparison would be an eventual staged renovation, starting now, with one-step deep renovation at an uncertain time in the future.

The energy use intensity (EUI) for the "base building" scenario was $190.38 \mathrm{Kwhpe} / \mathrm{m}^{2}$. Note that a preliminary energy analysis of the building showed that the use of an efficient natural gas condensing boiler for the heating system instead of electric radiators powered by electricity delivered directly by the energy company represented about $27 \%$ in primary energy consumption reduction. With the installation of the retrofit package B7, the EUI was $155.84 \mathrm{Kwhpe} / \mathrm{m}^{2}$, which appears to correspond to a relatively low energy efficient building. However, the minimum energy performance requirement for new hotel buildings in O'Porto city, which has a warmer winter season (Zone W2 S2) than that of the building location, is $158.31 \mathrm{Kwhpe} / \mathrm{m}^{2}$ and the cost-optimal solution is $138.79 \mathrm{Kwhpe} / \mathrm{m}^{2}$. According to Portugal's 2030 National Energy and Climate Plan [84], the milestones for primary energy consumption reduction in buildings are $11 \%, 27 \%$ and $40 \%$ for, respectively, 2030, 2040 and 2050, with 2018 as the reference year. Considering a further tightening on the regulatory requirements of the energy performance of buildings, an additional primary energy consumption reduction of about 30\% in the period 2030-2050 would lead to a building with NZEB requirements. Note that these requirements for existing buildings are calculated according to the cost-optimal methodology [34]. For the renovation steps of the building, the useful lives of the retrofit options and that of the natural gas boiler for the heating system need to be considered. As stated before, the useful lives were set up as following: insulation materials (for vertical and horizontal elements of the building) - 30 years; the natural gas boiler and the aerothermal heat pump - 20 years. According to a survey of the building, the glazing system will, by 2030 or so, reach the end of its useful life. The SPB of the aerothermal heat pump was about 10.5 years and that of the natural gas boiler, according to a preliminary analysis, was 8.6 years. So, a prospect for the following renovation steps of the building would be: for 2030-replacement of existing glazing system with a more efficient one; for 2040-replacement of the aerothermal heat pump and of the natural gas boiler with efficient energy generation systems powered by renewable energy sources.

The renovation of the Portugal's building stock, as well as those of many countries in the EU, represents a daunting challenge to be implemented in a thirty-year time horizon. In Portugal, based on recent experiences, macroeconomic and financial difficulties will undoubtedly aggravate the situation. One-step deep renovations require a large amount of public (national and EU) funding to finance de high upfront costs that characterize these works. However, given the scale of investment required [34], the extent to which the day-to-day government spending alone can deliver this may be limited [80]. Public buildings apart, the great majority of the government intervention (either through fiscal and/or financial incentives) will be directed at the housing segment. This policy should be balanced with public policy actions that lower market interest rates, which would also enhance the development of staged renovation works in the private commercial and service building segment.

\section{Conclusions}

This research has assessed the energy performance of an existing large office building before the pre-1960 age. The construction characteristics of this building represented a constraint to façade modification, as it happens, generally, in interventions in historical buildings [31]. This constraint entailed the selection of alternative energy renovation choices instead of external insulation. Additionally, the available budget also represented a constraint to the investment costs. Two passive technologies applied to the building 
envelope and an efficient domestic hot water system were selected and a financial evaluation through the net saving (NS) method was undertaken to choose the best efficiency measures/packages for improving the building's energy performance. The real discount rates used in the financial analysis were $3 \%$ and $1 \%$. By using the real discount rate of $3 \%$, only two out of seven energy efficiency measures/packages were profitable. However, those positive financial results were relatively high, considering the low values of investment costs. With a real discount rate of $1 \%$, all retrofit options were financially efficient. The results of the study keep with the results of earlier studies $[55,62,73]$ that found that the lower the interest rates used in energy renovating investments the higher the financial results tend to be. This study corroborated the results of previous studies $[62,85]$ that showed that retrofit solutions that do not include improvements on the building envelope are generally the most cost-effective options. The results of the study also suggested that the staged renovation approach used in the analysis is economically feasible, and that this approach is an alternative to one-step renovation approach to help to achieve the country's energy and climate targets by 2030 .

This study can help to inform public policy in two ways. The first has to do with the compliance with the obligations contained in the Article 2a of the EPBD. The review of EU and Portugal's policy frameworks indicates that Portugal's 2nd LTRS did not provide any information on the cost-effectiveness approach to renovation. Like in most MS, the majority of building renovation projects in Portugal is in the light-to-moderate range. Thus, a staged approach to renovation appears to be more compatible (at least in the medium-term horizon) with the reality of the market. An analysis that identifies profitable approaches to renovation in specific building clusters (and with different renovation scenarios) would be an effective way to help to motivate the stakeholders of the building renovation market. The second way (connected to the first) has to do with the link between national public financial aid available for the initial investment and the country's long-term energy and climate goals. This study suggests that an approach to assess the effectiveness of energy retrofit investment, at the macroeconomic pointed of view, is to compare the investment-tothe-building-construction-cost ratio with the rate of primary energy reduction.

The paper has some limitations. Firstly, our analysis was limited to a building that is representative of a particular building cluster (buildings of the pre-1960 age). Additionally, the study covers one (Zone W3V2) of the six climate zones of Portugal mainland only. In Portugal, buildings built before 1990 were constructed without thermal regulations. Thus, this study could be extended to buildings belonging to the same building archetype in other climate zones as well as buildings pertaining to other age groups.

Second, the sensitivity analysis developed in this study comprised the selection of interest rates only. As energy prices are also an important economic parameter for assessing the financial viability of building renovation investments, ours results may suffer from the choice of constant (in real terms) energy prices throughout the study period. Thus, a further study should contemplate different scenarios of discount rates and escalation rates of energy prices. This analysis would give a more accurate picture of the economic feasibility of the interventions.

Third, our analysis assessed the economic and energy performance of selected energy retrofitting measures/packages. EU and national policies call for the transformation of national building stock to NZEB requirements. These require not only the reduction in primary energy consumption but also the reduction in GHG emissions. Further studies should be extended to combine cost, energy and life cycle analyses.

Finally, regarding studies related to national strategies, they would be based on a wide sample of representative building archetypes. These analyses, ideally directed at the urban scale, would allow a better identification of the suitable range of energy performance that is reasonable to promote in different types of buildings. These would constitute useful complements to studies dealing with the macroeconomic and financial evaluation of the national building stock. 
Author Contributions: Conceptualization, J.L. and A.B.; Formal analysis, J.L., R.A.F.O. and A.B.; Investigation, R.A.F.O.; Methodology, J.L., R.A.F.O., N.B. and A.B.; Project administration, J.L., N.B. and A.B.; Resources, R.A.F.O.; Software, R.A.F.O.; Supervision, J.L. and N.B.; Validation, J.L., R.A.F.O., N.B. and A.B.; Visualization, R.A.F.O.; Writing-original draft, J.L. and R.A.F.O.; Writingreview \& editing, J.L., N.B. and A.B. All authors have read and agreed to the published version of the manuscript.

Funding: This research received no external funding.

Institutional Review Board Statement: Not applicable.

Informed Consent Statement: Not applicable.

Data Availability Statement: Not applicable.

Conflicts of Interest: The authors declare no conflict of interest.

$\begin{array}{ll}\text { Abbreviations } \\ \text { DHW } & \text { Domestic hot water } \\ \text { E } & \text { Electricity } \\ \text { EEM } & \text { Energy efficiency measures } \\ \text { EUI } & \text { Energy use intensity }\left(\mathrm{Kwhpe} / \mathrm{m}^{2}\right) \\ \text { HP } & \text { Heat pump } \\ \text { Ir } & \text { Internal insulation of the roof } \\ \text { Iv } & \text { Internal insulation of the vertical envelope } \\ \text { LCC } & \text { Life cycle cost } \\ \text { Kwhpe } & \text { Kilowatt hour primary energy } \\ \text { NPV } & \text { Net present value } \\ \text { NS } & \text { Net savings } \\ \text { PEF } & \text { Primary energy factor } \\ \text { RES } & \text { Renewable energy systems } \\ \text { SPB } & \text { Single payback } \\ U & \text { Thermal transmittance coefficient }\left(\mathrm{W} / \mathrm{m}^{2}{ }^{\circ} \mathrm{C}\right)\end{array}$

\section{References}

1. Government of Portugal. Roadmap for Carbon Neutrality 2050 (RNC50): Long-Term Strategy for Carbon Neutrality of the Portuguese Economy. Report 262/2019; Government Publications: Lisbon, Portugal, 2019.

2. European Parliament; Council of the European Union. Directive 2018/844/EC of the European Parliament and of the Council of 30 May 2018 Amending Directive 2010/31/EC on Energy Performance of Buildings and Directive 2012/27/EC on Energy Efficiency. 2018. Available online: https:/ / eur-lex.europa.eu/legal-content/EN/TXT/?uri=uriserv\%3AOJ.L_.2018.156.01.0075. 01.ENG (accessed on 25 July 2021).

3. Huang, M.; Zhang, X.; Ren, R.; Liao, H.; Zavadskas, E.K.; Antuchevičienè, J. Energy-saving building program evaluation with an integrated method under linguistic environment. J. Civ. Eng. Manag. 2020, 26, 447-458. [CrossRef]

4. European Parliament; Council of the European Union. Factsheets: Buildings in EU Countries: Portugal, 25 November 2016 , Last Update 20 May 2020. Available online: https:/ / ec.europa.eu/energy/sites/ener/files/documents/port.pdf (accessed on 25 July 2021).

5. IPCC. Climate Change, 2014: Synthesis Report. Contribution of Working Groups I, II and III to the Fifth Assessment Report of the Intergovernmental Panel on Climate Change; IPCC: Geneva, Switzerland, 2015. Available online: https://www.ipcc.ch/site/assets/ uploads/2018/05/SYR_AR5_FINAL_full_wcover.pdf (accessed on 16 July 2021).

6. Kamari, A.; Jensen, S.R.; Corrao, R.; Kirkegaard, P.H. A holistic multi-methodology for sustainable renovation. Int. J. Strateg. Prop. Manag. 2019, 23, 50-64. [CrossRef]

7. Ramesha, T.; Prakasha, R.; Shukla, K.K. Life cycle energy analysis of buildings: An overview. Energy Build. 2010, 42, 1592-1600. [CrossRef]

8. Capros, P.; De Vita, A.; Tasios, N.; Siskos, P.; Kannavou, M.; Petropoulos, A.; Evangelopoulou, S.; Zampara, M.; Papadopoulos, D.; Paroussos, L.; et al. EU Energy, Transport and GHG Emissions- Trends to 2050. A Report Prepared for the Directorate-General for Climate Action and the Directorate-General for Mobility and Transport by E3M-Lab of the ICCS-NTUA, Greece. 2016. Available online: https:/ / ec.europa.eu/energy/sites/ener/files/documents/20160713\%20draft_publication_REF2016_v13.pdf (accessed on 22 July 2021).

9. Economidou, M. Europe's Building under the Microscope; BPIE Publications: Brussels, Belgium, 2011.

10. DGEG. Long-Term National Strategy for the Mobilisation of Investment in Building Renovation; DGEG: Lisbon, Portugal, 2019. 
11. Fabbri, M.; De Groote, M.; Rapf, O. Building Renovations Passport-Customised Roadmaps towards Deep Renovations and Better Homes. A Report Prepared for BPIE. 2016. Available online: http://bpie.eu/wp-content/uploads/2017/01/Building-PassportReport_2nd-edition.pdf (accessed on 22 July 2021).

12. European Parliament; Council of the European Union. Directive 2018/2002/EC of the European Parliament and of the Council of 11 December 2018 Amending Directive 2012/27/EC on Energy Efficiency. 2018. Available online: https: / / eur-lex.europa.eu/ legal-content/EN/EN/TXT/PDF/?uri=CELEX:32018L2002\&rid=7 (accessed on 25 July 2021).

13. European Parliament; Council of the European Union. Directive 2018/2001/EC of the European Parliament and of the Council of 11 December 2018 on the Promotion of the Use of Energy from Renewable Sources (Recast). 2018. Available online: https: / / eur-lex.europa.eu/legal-content/EN/TXT/PDF/?uri=CELEX:32018L2001\&from=EN (accessed on 25 July 2021).

14. Castellazi, L.; Zangheri, P.; Paci, D.; Economidou, M.; Labanca, N.; Ribeiro Serrenho, T.; Panev, S.; Zancanela, P.; Broc, J.S. Assessment of Second Long-Term Renovation Strategies under the Energy Efficiency Directive. Joint Research Centre (JRC) for Policy Report, the European Commission. 2019. Available online: https://ec.europa.eu/jrc/en/publication/assessment-secondlong-term-renovation-strategies-under-energy-efficiency-directive (accessed on 25 July 2021).

15. European Parliament; Council of the European Union. Commission Delegated Regulation 244/2012/EC of 16 January 2012 Supplementing Directive 2010/31/EC of the European Parliament and of the Council on the Energy Performance of Buildings by Establishing a Comparative Methodology Framework for Calculating Cost-Optimal Levels of Minimum Energy Performance Requirements for Buildings and Building Elements. 2012. Available online: https://eur-lex.europa.eu/legal-content/GA/TXT/ ?uri=CELEX:32012R0244 (accessed on 25 July 2021).

16. Aguiar, R.; Graça, J. Custo-ótimo: Residências Isoladas Novas. Relatório em Cumprimento da Diretiva 2010/31/EU (EPBD) e Regulamento Delegado (UE) $n^{\circ}$ 244/2012, Relativo ao Cálculo dos Níveis Ótimos de Rentabilidade dos Requisitos Mínimos de Desempenho Energético dos Edifícios e Componentes de Edifício; DGEG: Lisbon, Portugal, 2019. (In Portuguese)

17. Economidou, M.; Bertoldi, P. Financing Energy Renovations in the European Building Stock. JRC for Policy Report, the European Commission. 2014. Available online: https:/ / e3p.jrc.ec.europa.eu/articles/financing-energy-renovations-european-buildingstock (accessed on 22 July 2021).

18. Schleich, J.; Grassmann, X.; Faure, C.; Meissner, T. Making the implicit explicit: A look inside the implicit discount rate. Energy Policy 2016, 97, 321-331. [CrossRef]

19. European Parliament; Council of the European Union. Communication from The Commission to the European Parliament, the Council, the European Economic and Social Committee and Committee of the Regions. A Renovation Wave for Europe-greening our Buildings, Creating Jobs, Improving Lives. SWD (2020) 550 Final. 2020. Available online: https:/ / eur-lex.europa.eu/resource. html?uri=cellar:0638aa1d-0f02-11eb-bc0701aa75ed71a1.0003.02/DOC_1\&format=PDF (accessed on 25 July 2021).

20. Bertoldi, P.; Boza-Kiss, B.; Della Vale, N.; Economidou, M. The role of one-stop shop in energy renovation-a comparative analysis of OSSs cases in Europe. Energy Build. 2021, 250, 111273. [CrossRef]

21. Abreu, I.; Oliveira, R.; Lopes, J. Younger vs. Older homeowners in building energy-related renovations. Learning from the Portuguese case. Energy Rep. 2020, 6, 159-164. [CrossRef]

22. European Parliament; Council of the European Union. Regulation (EU) 2021/241 of the European Parliament and of the Council of 12 February 2021 Establishing the Recovery and Resilience Facility. 2021. Available online: https:/ / eur-lex.europa.eu/legalcontent/EN/TXT/PDF/?uri=CELEX:32021R0241\&from=EN (accessed on 25 July 2021).

23. European Parliament; Council of the European Union. Regulation (EU) 2021/119 of the European Parliament and of the Council of 30 June 2021 Establishing the Framework for Achieving Climate Neutrality and Amending Regulations (EC) No 401/2009 and (EU) 2018/1999 ('European Climate Law'). 2021. Available online: https://eur-lex.europa.eu/legal-content/EN/TXT/PDF/ ?uri=CELEX:32021R1119\&from=EN (accessed on 25 July 2021).

24. European Court of Auditors. Energy Efficiency in Buildings: Greater Focus on Cost-Effectiveness is Still Needed. Special Report, European Court of Auditors, Luxembourg. 2020. Available online: https://www.eca.europa.eu/Lists/ECADocuments/SR20_11 /SR_Energy_efficiency_in_buildings_EN.pdf (accessed on 22 July 2021).

25. European Parliament; Council of the European Union. Directive 2012/27/EU of the European Parliament and of the Council of 25 October 2012 on Energy Efficiency, Amending Directives 2009/125/EC and 2010/30/EU and Repealing Directives 2004/8/EC and 2006/32/EC. 2012. Available online: https:/ / eur-lex.europa.eu/legal-content/EN/TXT/?uri=celex\%3A32012L0 027 (accessed on 25 July 2021).

26. Fritz, S.; Pehnt, M.; Mellwig, P.; Volt, J. Planned Staged Deep Renovations as the Main Driver for a Decarbonised European Building Stock. ECEEE Summer Study. 2019. Available online: file:/ / C:/Users/Jorge/Downloads/7-242-19_Fritz\%20.pdf (accessed on 22 July 2021).

27. Vilarejo, P.; Gámez, R.; Santamaria-López, A. Building renovation passports in Spain: Integrating exiting instruments for building conservation, renovation and heritage protection. Energy Policy 2021, 157, 112506. [CrossRef]

28. Sesana, M.; Rivallain, M.; Salvalai, G. Overview of the available knowledge for the data model definition of a Building Renovation Passport for non-residential buildings: The ALDREN Project experience. Sustainability 2020, 12, 642. [CrossRef]

29. Sesana, M.; Salvalai, G. A review on Building Renovation Passport: Potentialities and barriers on current initiatives. Energy Build. 2018, 173, 195-205. [CrossRef]

30. Van de Moortel, E.; de Troyer, F.; Allacker, K.; Stijnen, L.; Schoofs, E. Avoiding financial lock-in effects in case of a stepwise energy renovation of social housing in Flanders. WPE 2019, 4, 160-176. [CrossRef] 
31. Semprini, G.; Gulli, R.; Ferrante, A. Deep renovations versus shallow renovation to achieve nearly zero energy in existing buildings: Energy savings and economic impact of design solutions of the housing stock in Bologna. Energy Build. 2017, 156, 327-342. [CrossRef]

32. Effinergy. Bâtiment Basse Consommation en renovation; Effinergy: Montpellier, France, 2011; Available online: https://www. effinergie.org/web/images/divers/guides/reno/Guide\%20Renovation.pdf (accessed on 25 July 2021). (in French)

33. Portuguese Energy Agency. Energy Efficiency Trends and Policies in Portugal. Portuguese Energy Agency-ADENE, July 2018. Available online: https:/ / www.odyssee-mure.eu/publications/national-reports/energy-efficiency-portugal.pdf (accessed on 22 July 2021).

34. Government of Portugal. Estratégia de Longo Prazo para a Renovação de Edifícios: Resolution of Council of Ministers ${ }^{\circ}$ 8-A/2021 published in Government Gazette, 3 of February 2021, Lisbon, Portugal. 2021. Available online: https://dre.pt/ application/conteudo/156295372 (accessed on 22 July 2021). (In Portuguese)

35. Government Gazette. Decree/Law 40/90 of 6 February 1990. 1990. Available online: https://dre.pt/application/conteudo/3346 11 (accessed on 15 July 2021).

36. Nicholls, C. Energy use in non-domestic buildings: The UK Government's new evidence base. Build. Res. Inf. 2014, $42,109-117$. [CrossRef]

37. Ruegg, R.; Marshall, H. Building Economics: Theory and Practice, 1st ed.; Springer Science +Business Media: New York, NY, USA, 1990.

38. Chapman, R.; Kasi, M. Benefits of Using ASTM Building Economics Standards for the Design, Construction, and Operation of Constructed Facilities; NIST Special Publication 1098; US Department of Commerce National Institute of Standards and Technology: Washington, DC, USA, 2012.

39. Almeida, M.; Ferreira, M. Ten questions concerning cost-effective energy and carbon emissions optimization in building renovation. Build. Environ. 2018, 143, 15-23. [CrossRef]

40. Tadeu, S.; Alexandre, R.; Tadeu, A.; Antunes, C.; Simões, N.A.V.; da Silva, P. A comparison between cost optimality and return on investment for energy retrofit buildings-A real options perspective. Sustain. Cities Soc. 2016, 21, 12-25. [CrossRef]

41. Directorate-General for Energy and Geology-DGEG. Cálculo dos Níveis Ótimos de Rentabilidade dos Requisitos Mínimos de Desempenho Energético dos Edifícios e Componentes de Edifícios: Edifícios Hoteleiros; DGEG \& ADENE: Lisbon, Portugal, 2013. (In Portuguese)

42. Pinto, A. Estudo de Cálculo dos Níveis Ótimos de Rentabilidade dos Requisitos Mínimos de Desempenho Energético dos Edifícios e Componentes de Edifícios; Report 473/2014-DED/NAICI; DGEG: Lisbon, Portugal, 2014. (In Portuguese)

43. DGEG; ADENE. Calculation of Cost-Optimal Levels of the Minimum Energy Performance Requirements of Buildings and Building Elements: Hotel Buildings; DGEG \& ADENE: Lisbon, Portugal, 2019.

44. Ballarini, I.; Corrado, V.; Madonna, F.; Paduos, S.; Ravasio, B. Energy refurbishment of the Italian residential building stock: Energy and cost analysis through the application of the building typology. Energy Policy 2017, 105, 148-160. [CrossRef]

45. Aguacil, S.; Lufkin, S.; Rey, E.; Cuchi, A. Application of the cost-optimal methodology to urban renewal projects at the territorial scale based on statistical data. A case study in Spain. Energy Build. 2017, 144, 42-60. [CrossRef]

46. Pallis, P.; Gkonis, N.; Varvagianis, E.; Braimakis, K.; Karelas, S.; Katsaros, M.; Vourliotis, P. Cost effectiveness assessment and beyond. A case study on energy efficiency intervention in Greek residential building stock. Energy Build. 2019, 182, 1-18. [CrossRef]

47. Vasconcelos, A.; Pinheiro, M.; Manso, A.; Cabaço, A. A Portuguese approach to define reference buildings for cost-optimal methodologies. Appl. Energy 2015, 140, 316-328. [CrossRef]

48. Fernandes-Luzuriaga, J.; Portillo-Valdes, L.; Flores-Abascal, I. Identification of cost-optimal levels for energy refurbishment of a residential building stock under different scenarios: Application at the urban scale. Energy Build. 2021, 240, 110880. [CrossRef]

49. Panagiotidu, M.; Aye, L.; Rismanchi, B. Optimisation of multi-residential building retrofit, cost-optimal and net-zero emission targets. Energy Build. 2021, 252, 111385. [CrossRef]

50. Galimishina, A.; Moustapha, M.; Hollberg, A.; Padey, P.; Lasvaux, S.; Sudret, S.; Habert, G. What is the optimal robust environmental and cost-effective solution for building renovation? Not the usual one. Energy Build. 2021, 251, 111329. [CrossRef]

51. Pannier, M.L.; Retcht, T.; Robillart, M.; Schallbart, P.; Peuportier, L.B.; Mora, M.L. Identifying optimal renovation schedules for building portfolios: Application in a social housing context under multi-year funding constraints. Energy Build. 2021, 250, 111290. [CrossRef]

52. Moran, P.; O' Connel, J.; Goggins, J. Sustainable energy efficiency retrofits as residential buildings move towards nearly zero energy building (NZEB) standards. Energy Build. 2020, 211, 109816. [CrossRef]

53. Antonov, Y.; Heiselberg, P.; Flourentzou, F.; Pomianolwski, M. Methodology for evaluation and development of refurbishment scenarios for multi-storey apartment buildings, applied to two buildings in Denmark and Switzerland. Buildings 2020, 10, 102. [CrossRef]

54. Harkouss, F.; Fardoum, F.; Biwole, P. Multi-objective optimization methodology for net zero energy buildings. J. Build. Eng. 2018, 16, 57-71. [CrossRef]

55. Conci, M.; Thaleia, K.; van den Dobbelsteen, A.; Schneider, J. Trade-off between the economic and environmental impact of different decarbonisation strategies for residential buildings. Build. Environ. 2019, 155, 137-144. [CrossRef]

56. Ascione, F.; Bianco, N.; De Stazio, C.; Mauro, G.M.; Vanoli, G.P. A new methodology for cost-optimal analysis by means of the multi-objective optimization of building energy performance. Energy Build. 2015, 88, 78-90. [CrossRef] 
57. Pikas, E.; Thafelddt, M.; Kurnitski, J. Cost optimal and nearly zero energy building solutions for office buildings. Energy Build. 2014, 74, 30-42. [CrossRef]

58. Rabani, M.; Madessa, H.; Mohseni, O.; Nord, N. Minimizing delivered energy and life cycle cost using Graphica script: An office building retrofitting case. Appl. Energy 2020, 268, 114929. [CrossRef]

59. Gangolells, M.; Gaspar, K.; Casals, M.; Ferré-Bigorra, J.; Forcada, N.; Macarulla, M. Life-Cycle Environmental and Cost-Effective Energy Retrofitting Solutions for Office Stock. Sustain. Cities Soc. 2020, 61, 102319. [CrossRef]

60. Gustafsson, M.; Dipasquale, C.; Poppi, S.; Bellini, A.; Fedrizzi, R.; Bales, C.; Ochs, F.; Sie, M.; Holmberg, S. Economic and environmental analysis of energy renovation packages for European office buildings. Energy Build. 2017, 148, 155-165. [CrossRef]

61. Niemela, T.; Levy, K.; Kosonen, R.; Jokisolo, J. Cost-optimal renovation solutions to maximize environmental performance, indoor thermal conditions and productivity of office buildings in cold climate. Sustain. Cities Soc. 2017, 32, 417-434. [CrossRef]

62. Ferrari, S.; Beccali, M. Energy-environmental and cost assessment of a set of strategies for retrofitting a public building toward nearly zero-energy building target. Sustain. Cities Soc. 2017, 32, 226-234. [CrossRef]

63. Mora, T.D.; Righi, A.; Peron, F.; Romagnoni, P. Cost-optimal measures for renovation of existing school buildings towards nZEB. Energy Procedia 2017, 140, 288-302. [CrossRef]

64. Ozbalta, T.; Yildiz, Y.; Bayram, I. Energy performance analysis of a historical building using cost-optimal assessment. Energy Build. 2021, 250, 111301. [CrossRef]

65. Ferreira, M.; Almeida, M.; Rodrigues, A.; Silva, S.M. Comparing cost-optimal and net-zero energy targets in building retrofit. Build. Res. Inf. 2014, 44, 188-201. [CrossRef]

66. Tadeu, S.; Rodrigues, C.; Tadeu, A.; Freire, F.; Simões, F. Energy retrofit of historic buildings: Environmental assessment of cost-optimal solutions. J. Build. Eng. 2015, 4, 167-176. [CrossRef]

67. Rodrigues, F.; Parada, M.; Vicente, R.; Oliveira, R.; Alves, A. High energy efficiency retrofits in Portugal. Energy Procedia 2015, 83, 187-196. [CrossRef]

68. Government Gazette. Ministerial Decision $n^{\circ}$ 15793-E/2013, of 2 December 2013. 2013. Available online: https://dre.pt/ application/conteudo/2975218 (accessed on 15 July 2021).

69. Santos, C.; Matias, L. Coeficientes de Transmissão Térmica de Elementos da Envolvente de Edifícios-ITE 50; National Laboratory for Civil Engineering, ICT: Lisbon, Portugal, 2006. (In Portuguese)

70. Government Gazette. Ministerial Decision $\mathrm{n}^{\circ}$ 15793-F/20132 of 2 December 2013. 2013. Available online: https://dre.pt/ application/conteudo/2975219 (accessed on 15 July 2021).

71. Government Gazette. Decree-Law n¹01-D/2020 of 7 de December, Transposing the Directive (UE) 2018/844 and partially the Directive (UE) 2019/944. 2020. Available online: https:/ / dre.pt/application/conteudo/150570704 (accessed on 25 July 2021).

72. Government Gazette. Ministerial Order $\mathrm{n}^{\circ}$ 138-I/2021 of 1 July 2021. 2021. Available online: https://dre.pt/application/ conteudo/166296492 (accessed on 25 July 2021).

73. Cova, S.; Andrade, C.; Soares, O.; Lopes, J. Evaluation of cost-optimal retrofit investment in buildings: The case of Bragança fire station, Portugal. Int. J. Strateg. Prop. Manag. 2021, 25, 369-381. [CrossRef]

74. Government Gazette. Ministerial Order n ${ }^{\circ}$ 349-D/2013 of 2 December 2013. 2013. Available online: https://dre.pt/application/ conteudo/263693 (accessed on 15 July 2021).

75. Steinbach, J.; Staniaszek, D. Discount Rates in Energy System Analysis: Discussion Paper; Buildings Performance Institute Europe (BPIE): Berlin, Germany, 2015.

76. Bogdan, A.; Ilektra, K. Implementing Cost-Optimal Methodology in EU Countries: Lessons from Three Case Studies. Building Performance Institute Europe (BPIE). 2013. Available online: https:/ / www.bpie.eu/publication/implementing-thecost-optimal-methodology-in-eu-countries/ (accessed on 22 July 2021).

77. Hermelink, A.; de Jager, J. Evaluating our Future-The Crucial Role of Discount Rates in European Commission Energy System Modelling. The European Council for an Energy Efficient Economy \& Ecofys. 2015. Available online: https://www.eurima.org/ uploads/ModuleXtender/Publications/129/Ecofys_EvaluatingOurFuture-final20151019.pdf (accessed on 22 July 2021).

78. Pordata. Interest Rates on New Loan Operations (Annual Average) to Individuals: Total and by Purpose Type. Retrieved 15 July 2021. Available online: https:/ /www.pordata.pt/en/Portugal/Interest+rates+on+new+type-2845 (accessed on 22 July 2021).

79. Cype Ingenieros. Software for Architecture, Engineering and Construction. 2021. Available online: http:/ / programs.en.cype.com/ (accessed on 24 July 2021).

80. Brown, D.; Sorrell, S.; Kivimaa, P. Worth the Risk? An evaluation of alternative finance mechanisms for residential retrofit. Energy Policy 2019, 128, 418-430. [CrossRef]

81. Government Gazette. Ministerial Decision $\mathrm{n}^{\circ}$ 15793-D/2013 of 2 December 2013. 2013. Available online: https://dre.pt/ application/conteudo/2975217 (accessed on 15 July 2021).

82. ZEBRA 2020. Nearly Zero-Energy Building Strategy 2020: Strategies for a Nearly Zero-Energy Building Market Transition in the European Union. 2016. Available online: https://www.zebra2020.eu/website/wp-content/uploads/2014/08/ZBRA2020_ Strategies_Strategies-for-nZEB_07_LQ_single-pages-1.pdf (accessed on 22 July 2021).

83. Government Gazette. Ministerial Order n 3/2020 of 13 January 2020. 2020. Available online: https://dre.pt/application/ conteudo/127970106 (accessed on 25 July 2021). 
84. Government of Portugal. National Energy and Climate Plan 2030 (PNEC 2030): Resolution of Council of Ministers $n^{\circ} 53 / 2020$; Government Gazette: Lisbon, Portugal, 2020. (In Portuguese)

85. Kapsalaki, M.; Leal, V.; Santamouris, M. A Methodology for Economic Efficient Design of Net Zero Energy Buildings. Energy Build. 2012, 55, 765-778. [CrossRef] 